\title{
CYP1A2*1 Allele
}

National Cancer Institute

\section{Source}

National Cancer Institute. CYP1A2*1 Allele. NCI Thesaurus. Code C46037.

Human CYP1A2*1 allele is located within $15 \mathrm{q} 24$ and is approximately $8 \mathrm{~kb}$ in length. This allele, a variant form of the CYP1A2 wild-type allele, encodes cytochrome P450 1A2*1 protein. There are multiple haplotypes of the CYP1A2*1 allele. Both CYP1A2*1C, which has a SNP (g.-3860G>A) in the 5 ' flanking region of the gene, and CYP1A2*1K, which has a SNP (g.-729C>T) in intron 1, encode cytochrome P450 1A2*1 proteins that exhibit decreased in vivo enzymatic activity. CYP1A2*1F exhibits a SNP (g.-163C>A) in intron 1 that has been linked with higher enzyme inducibility. 